\title{
Assessment of Young and Aged Hematopoietic Stem Cell Activity by Competitive Serial Transplantation Assays
}

\section{Yu Wei Zhang and Nina Cabezas-Wallscheid}

\begin{abstract}
Healthy hematopoietic stem cells (HSCs) are capable to self-renew and reconstitute the complete hematopoietic system. Upon aging, there is an increased incidence of blood-related diseases. Age-related phenotypes have been widely studied by bone marrow transplantation experiments, where reconstitution of the transplanted cells is a direct measure of HSC activity. In this protocol we describe a competitive bone marrow transplantation assay to functionally test young and old HSCs.
\end{abstract}

Key words Hematopoietic stem cells, Transplants, Young, Aged, Bone marrow, Competitive

\section{Introduction}

Hematopoietic stem cells (HSCs) hold the capacity to generate a series of multipotent progenitors that differentiate into lineagecommitted progenitors and subsequently mature cells [1-5]. HSCs remain quiescent for most of their life span $[6-9,18]$. By contrast, downstream committed progenitors show very high proliferative capacities [10-13]. The maintenance of the hematopoietic lineage is critical for homeostasis and enables the rapid and robust response to physiological stresses, such as cytokines, infection, and injury [14-17]. It remains to be elucidated how a stem cell determines whether to maintain its multipotency or to differentiate to generate mature cells.

Upon aging an increased frequency of anemias [19], myeloproliferative diseases, leukemia [20], as well as decreased lymphopoiesis $[21,22]$ have been observed. The manifestation of age-related defects in the HSC population can alter the functional dynamics of self-renewal and differentiation $[23,24]$. Several studies suggest that aged HSCs exhibit a myeloid bias, impaired DNA repair, and shortening of their telomeres which contribute to the decline in homing and reconstitution capacities [25-28]. Cell extrinsic 
alterations due to aging are associated with decreased bone marrow cellularity, enhanced adipogenesis, and changes in extracellular matrix components [29]. All these factors are inversely correlated with a decline in HSC function. Young HSCs transplanted to aged niches exhibit deficient homing and a decreased potential for differentiation as well as a bias to differentiate toward the myeloid lineage [30]. It is important to remember that some of these aging phenotypes are still debated and additional research is required to elucidate the biology of aged HSCs.

Transplantation assays is the golden standard method to address the functional potential of HSCs [31]. HSC potency is quantified by the frequency of their progeny over long periods of time. To distinguish cells derived from wild-type (WT) and genetically modified HSCs, researchers have utilized congenic C57BL/6 (CD45.2) and B6.SJL (CD45.1) mouse strains [32], as well as their Fl hybrids (CD45.1/2). Bone marrow cells are isolated from CD45.2 and CD45.1/2 donor mouse strains and transplanted into lethally irradiated CD45.1 recipient mice. Mouse monoclonal antibodies targeting specific epitopes in the CD45 regions are used to distinguish the origin of the hematopoietic cells $[33,34]$. In combination with blood lineage markers, the CD45.1-CD45.2 system allows experimenters to detect myeloid and lymphoid outcome, but not the erythroid differentiation potential of the two competitors.

Compared to WT congenic C57BL/6 (CD45.2) cells, WT B6. SJL (CD45.1) cells have been reported to show decreased homing efficiency, a reduced number of transplantable HSCs, and a cell intrinsic engraftment disadvantage [35]. WT C57BL/6 (CD45.2) cells show higher myeloid, $\mathrm{B}$ and $\mathrm{T}$ cell engraftment. The molecular cause of the inherent bias that causes an unfair advantage to CD45.2 is not well understood. Recently, a novel mouse strain has been developed to abolish this advantage [36]. This mouse model named CD45.1 ${ }^{\text {STEM }}$ was created de novo from the WT C57BL/6N (CD45.2) strain by a single amino acid change in the Ptprc gene encoding for the CD45 antigen, making it detectable with the CD45.1 antibody instead. CD 45.1 ${ }^{\text {STEM }}$ has been proven to be functionally equivalent to its CD45.2 counterpart [36]. Using

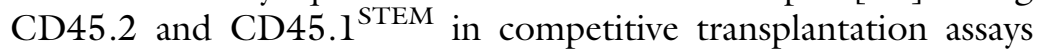
serves as a more accurate and fair comparison of HSC biology.

Here we present a transplantation protocol that will guide you through the necessary steps needed to plan and execute a successful competitive transplantation experiment for young and aged hematopoietic cells. Young hematopoetic cells of a genetically modified organism (GMO) (i.e., knockout) will compete against its young wild-type (WT) counterpart. Similarly, aged hematopoietic cells with the same genetic modifcation will compete with their aged WT counterpart. This competitive bone marrow transplantation scheme will delineate the importance of particular genes during aging. 


\section{Materials}

2.1 Selection of Mice (See Notes 1)

\subsection{Dissection and Isolation of Bone Marrow}

- For competitive assay CD45.2 and CD45.1/2 donor mice are transplanted into CD45.1 recipient mice (Fig. 1).

\begin{tabular}{|c|c|c|c|}
\hline Mice & Strain & Young & Old \\
\hline $\begin{array}{l}\text { CD45.2 donor } \\
\text { (GMO or WT) }\end{array}$ & C57BL/6 & $\begin{array}{l}8-12 \\
\text { weeks }\end{array}$ & $\begin{array}{l}\text { 18-24 } \\
\text { months }^{\mathrm{a}}\end{array}$ \\
\hline $\begin{array}{l}\text { CD } 45.1 / 2 \\
\text { competitor } \\
\text { (WT) }\end{array}$ & $\begin{array}{l}\text { F1 hybrid of } \\
\quad \text { C57BL } / 6 \times \text { B6.SJL }\end{array}$ & $\begin{array}{l}8-12 \\
\text { weeks }\end{array}$ & $\begin{array}{l}\text { 18-24 } \\
\text { months }^{\mathrm{a}}\end{array}$ \\
\hline $\begin{array}{l}\mathrm{CD} 45.1 \\
\quad \text { recipient }(\mathrm{WT})\end{array}$ & B6.SJL & $\begin{array}{l}\text { 8-12 } \\
\text { weeks }\end{array}$ & $\begin{array}{l}18-20 \text { months } \\
\quad \text { or } 8-12 \text { weeks }\end{array}$ \\
\hline
\end{tabular}

${ }^{a}$ Mice that are 18-24 months old are equivalent to the human age of 56-69 years old. Therefore, aged HSC mice used for the experiment should be older than 18 months. Of note, mice that are 10-14 months old are equivalent to the human age of 38-47 years old and thereby categorized as middle-aged [37].

${ }^{\mathrm{b}}$ The availability of 18 -month-old mice is usually limited. Therefore, some groups opt to use young mice as recipients. Take into consideration that the niche influences HSC behavior and therefore proper controls are needed.

- $\mathrm{CO}_{2}$ chamber (optional).

- $70 \%$ ethanol.

- Dissection tools (dissecting scissors, dissecting tray, iris forceps, steel dissecting pins, and scalpel).

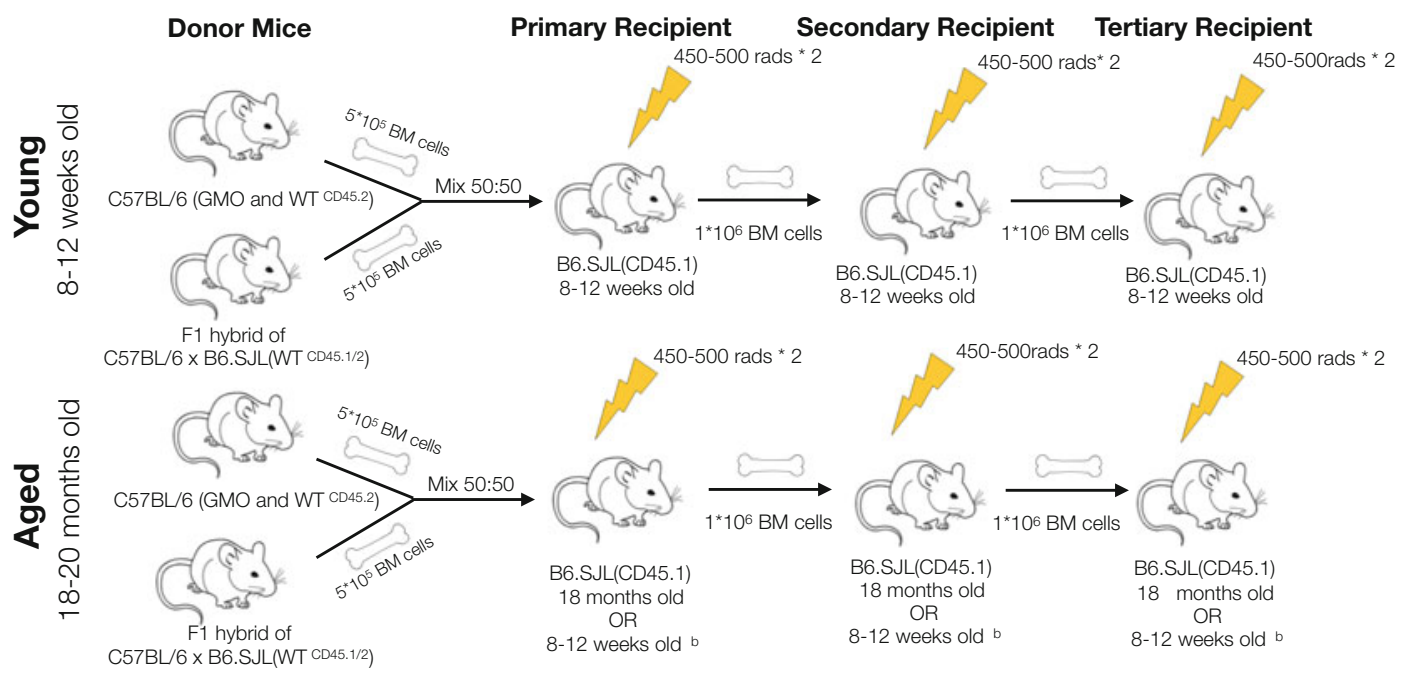

Fig. 1 Experimental strategy comparing HSC function of young or old mice. Bone marrow cells from donor WT, GM0 CD45.2 and competitor WT CD45.1/2 mice are isolated. A 50:50 mix of CD45.2:CD45.1/2 bone marrow cells are transplanted into lethally irradiated CD45.1 recipients (450-500 rad $\times 2$ times). At 16 weeks posttransplantation, the primary recipients are sacrificed, bone marrow cells are isolated and transplanted into secondary recipients. This process might be repeated if tertiary transplantations are required 
- Phosphate-buffered saline (PBS).

- 6-well plate filled with $5 \mathrm{ml} \mathrm{PBS}$.

- Mortar and pestle.

- $40 \mu \mathrm{m}$ cell strainer.

- $50 \mathrm{ml}$ Falcon tube.

- Cell counter (e.g., hemocytometer).

2.3 For Irradiation

- Supplemental antibiotic water: $5 \mathrm{ml}$ Trimethosel in 11 of tap water.

- Irradiator.

- Container.

2.4 For Injections

1. 29-gauge needles ( see Note 2).

2. $1 \mathrm{ml}$ syringe.

3. Gauze sponges.

4. Heating lamp or warm water bath (maximal $40^{\circ} \mathrm{C}$ ).

5. Restrainer.

6. $70 \%$ ethanol.

\subsection{FACS Analysis}

1. Blood lancet.

2. $1.5 \mathrm{ml}$ EDTA polypropylene microcentrifuge tube.

3. Erythrocyte-lysing buffer $\left(150 \mathrm{mM} \mathrm{NH}_{4} \mathrm{Cl}, 10 \mathrm{mM} \mathrm{KHCO}_{3}\right.$, $0.1 \mathrm{mM} \mathrm{Na}{ }_{2}$ EDTA; dissolve in $\mathrm{H}_{2} \mathrm{O} ; \mathrm{pH} \mathrm{7.2-7.4;} \mathrm{store} \mathrm{at}$ room temperature for up to 6 months).

4. PBS.

5. Fetal bovine serum (FBS).

6. Antibodies ( see Note 3).

\begin{tabular}{llll}
\hline Antibody & Fluorochrome & Population & Clone \\
\hline CD45.1 & Alexa Fluor 700 & CD45.1 mouse cells & A20 \\
\hline CD45.2 & APC-Cy7 & CD45.2 mouse cells & 104 \\
\hline CD11b & PE & Myeloid cells & Ml $/ 70$ \\
\hline CD3 & FITC & T cells & UCHT1 \\
B220 & APC & B-cells & RA3-6B2 \\
Gr-1 & PE-Cy7 & Granulocytes & RB6-8C5 \\
\hline & & &
\end{tabular}

7. FACS tubes conical $4.5 \mathrm{ml}$.

8. Flow cytometry device. 


\section{Methods}

\subsection{Preparation of Bone Marrow Cells for Transplantation}

Before performing the animal experiment, consult with the local animal welfare authorities or in-house animal specialists regarding the rules and regulations governing animal experiments in your region.

1. Euthanize donor mice through either cervical dislocation or $\mathrm{CO}_{2}$ asphyxiation.

2. Place mouse on its back, secure animal onto dissecting tray by pinning front palms so that they are raised diagonally from its body, and disinfect by spraying down with $70 \%$ ethanol.

3. Isolate the tibias, femurs, and hipbones and place into 6-well plate filled with ice-cold PBS. Excessive muscle tissue will loosen after $5 \mathrm{~min}$ in the PBS, and bones can be further cleaned using the scalpel to remove excess muscle tissue.

4. To isolate bone marrow cells, transfer bones to the mortar. Add $5 \mathrm{ml}$ of PBS and crash the bones thoroughly with the pestle. Grind bones until they lose their pink color and become pale white/pink.

5. Collect the cell suspension, and pipette up and down few times to break apart the clumps of cells.

6. Place a $40 \mu \mathrm{m}$ cell strainer over a $50 \mathrm{ml}$ Falcon tube, and filter the cell suspension from step 5 through it.

7. Wash the mortar with additional $5 \mathrm{ml}$ of PBS, and crush the bones for $20 \mathrm{sec}$. Again, filter the cell suspension through the cell strainer into the $50 \mathrm{ml}$ Falcon tube.

8 . For a competitive transplantation, ideally $2-5 \times 10^{5}$ total bone marrow cells from CD45.2 donor mice are supplemented with the same number of bone marrow cells from the CD45.1/ 2 competitor. The transplantation scheme is depicted below and shown in Fig. 1.

\begin{tabular}{llc}
\hline Age & Competition & Ratio of Injected Cells \\
\hline Young & $\left(\right.$ GMO or WT $^{\mathrm{CD} 45.2}:$ & $5 \times 10^{5} \mathrm{CD} 45.2:$ \\
& WT $^{\mathrm{CD} 45.1 / 2}$ & $5 \times 10^{5} \mathrm{CD} 45.1 / 2$ \\
Old & $\left(\mathrm{GMO}\right.$ or WT $^{\mathrm{CD} 45.2}:$ & $5 \times 10^{5} \mathrm{CD} 45.2:$ \\
& WT $^{\mathrm{CD} 45.1 / 2}$ & $5 \times 10^{5} \mathrm{CD} 45.1 / 2$ \\
\hline
\end{tabular}

9. Before transplantation, to confirm 50:50 ratio of CD45.2 to CD 45.1/2 bone marrow cells, prepare an aliquot of the cells from step 8. Stain aliquot with the antibodies against CD45.1 and CD45.2 and analyze by flow cytometry

10. Adjust the 50:50 mix of CD45.1 and CD45.1/2 cells from step 8 in a volume appropriate for intravenous injection (100 $\mu$ l per recipient). 


\subsection{Irradiation of Recipient Mice}

\subsection{Intravenous Injection of Total Bone Marrow Cell Suspension into the Lateral Tail Vein of Irradiated Recipient Mice}

1. 1-5 days prior to irradiation, place CD45.1 recipient mice on supplemental antibiotic water.

2. Place the recipient mouse into the acrylic container (see Note 4). Multiple mice can be irradiated simultaneously, depending on the size of the irradiator.

3. One day prior to injection, give the recipient mice a lethal dose of total body irradiation (TBI). Ideally, split the entire 900-950 rad lethal dose of TBI into two sublethal doses: $450 \mathrm{rad}$ in the morning and 4-6 h later another dose of 450-500 rad.

4. Give antibiotic water to irradiated mice for at least 14-28 days postirradiation and carefully monitor.

1. Prior to injection, warm up the tail of the recipient under the heat lamp or in warm water to dilate the lateral veins. Researchers using warm water need to maintain the temperature at $40{ }^{\circ} \mathrm{C}$.

2. For injection, place each mouse into a mouse restrainer (see Note 5).

3. Dampen a gauze sponge with $70 \%$ ethanol, and disinfect the injection site.

4. Using the non-dominant hand, hold the mouse at the most distal end of the tail (approximately 1/3 from the tip). Bend the tail over the index finger, and use the thumb to secure it to this position.

5. Locate the tail veins that run on the lateral sides of the tail.

6. Holding the syringe strictly parallel to the tail with the lumen of the needle facing upwards, insert the needle about $5 \mathrm{~mm}$ into the tail vein.

7. Inject slowly. In case of resistance, the needle should be removed and reinserted above the first site.

8. After injection, remove the needle without rotating or moving the needle while in the vein. Apply gentle compression to the tail until bleeding has stopped.

9. Mice need to be monitored for several days after transplantation since insufficient cell transplantation can lead to death within 2 weeks.

1. Restrain the mouse with the lateral surface of the head facing upwards. You can alternate between the two sides of the head every 4 weeks.

2. At this position, the superficial temporal vein runs from the orbit to the base of the ear diagonally. Use the lancet to stab halfway between the ear and the mandible using enough pressure to produce a small incision. 


\subsection{Analysis of Peripheral Blood by FACS}

3. The drops of blood should flow into the lancet and be collected into the EDTA-coated tube. Approximately, $100 \mu \mathrm{l}$ of blood can be collected with this method.

4. To stop the bleeding, place a light pressure on the cheek using gauze for a second.

1. To deplete red blood cells, add $500 \mu$ l of erythrocyte-lysing buffer to each tube, and incubate at room temperature for 5-10 min. For convenience, the cell suspension can be transferred into a $4.5 \mathrm{ml}$ FACS tube.

2. Add $2 \mathrm{ml}$ of PBS with $2 \%$ FBS to quench the red blood cell lysis buffer.

3. Centrifuge at $400 \times g$ for $5 \mathrm{~min}$. Aspirate the supernatant and be careful not to touch the bottom of the tube.

4. If red blood cells still remain, repeat the red cell lysis one to two additional times (steps $\mathbf{1 - 3}$ ) until there is a clear white/pink pellet.

5. Prepare complete antibody cocktail mix in PBS. In addition, prepare compensation tubes: single color controls and unstained control.

6. Add $50 \mu$ l of antibody cocktail mix per sample; vortex gently; incubate at $4{ }^{\circ} \mathrm{C}$ for $20 \mathrm{~min}$.

7. Add $2 \mathrm{ml}$ of PBS to wash cells; vortex gently

8. Centrifuge at $400 \times g$ for $5 \mathrm{~min}$, and aspirate supernatant leaving approximately 100-200 $\mu \mathrm{l}$ at the bottom. The tubes are now ready for FACS analysis.

9. The analysis of the different lineages of the peripheral blood can be performed using the gates described below (Fig. 2).

Peripheral blood analysis is performed starting at week 4 posttransplantation and then followed by intervals of 4 weeks between bleedings. At 16 weeks posttransplantation, mice are sacrificed, and bone marrow cells from the tibia, femur, and hipbones are harvested. Reconstitution analysis is performed on bone marrow cells. Approximately 20 million bone marrow cells are sufficient to analyze all types of reconstituted hematopoietic cells, including HSC cell cycle analysis. In case of impaired HSC self-renewal, this phenotype might be observed only upon serial transplantation [38]. Thus, secondary or even tertiary transplantation assays are recommended to assess long-term HSC activity. To perform secondary transplantation, $1-3 \times 10^{6}$ total bone marrow cells from the sacrificed recipients are injected into new cohort of irradiated CD45.1 mice. 

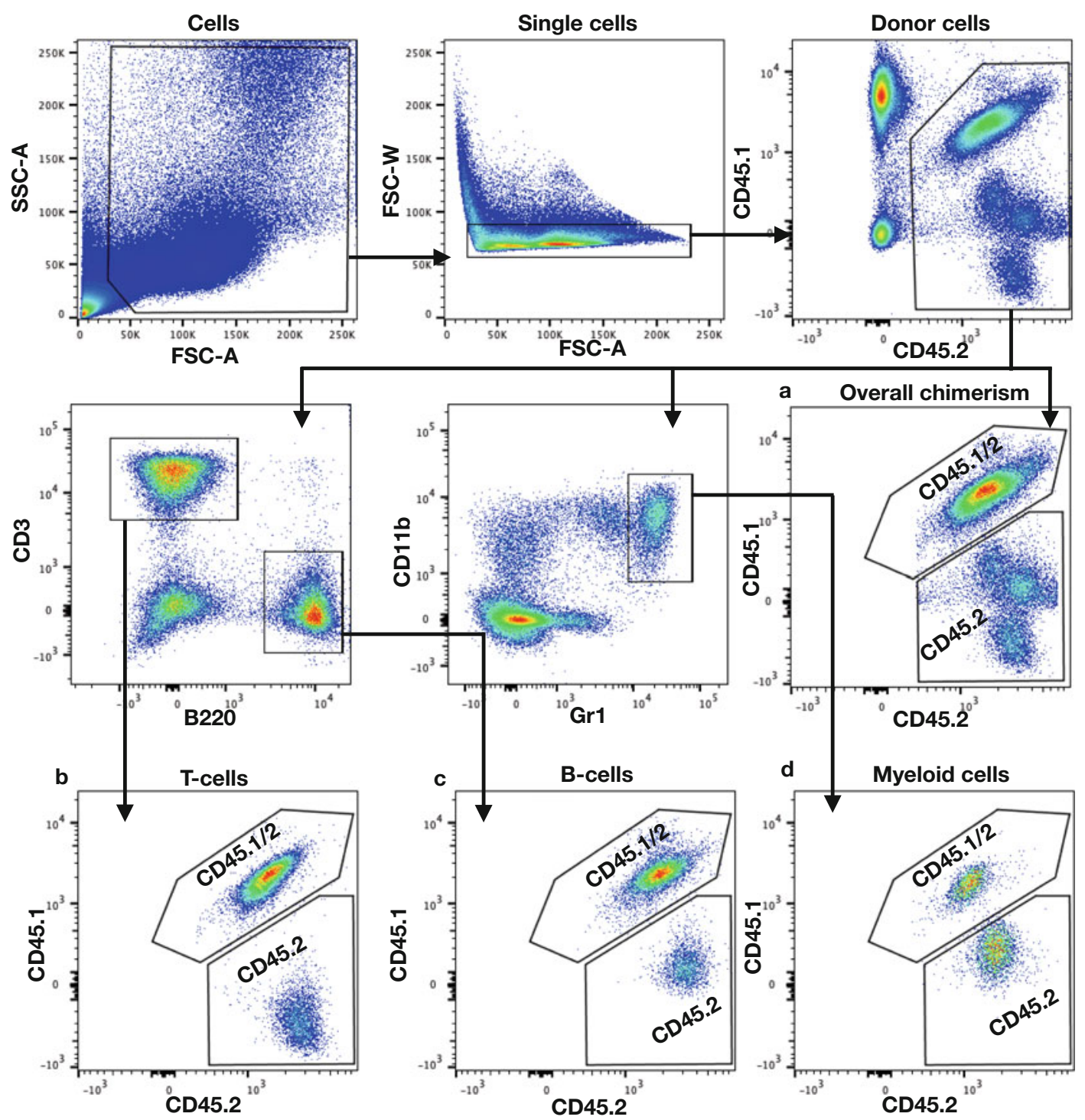

Fig. 2 FACS analysis of peripheral blood from transplanted mice. Representative gating scheme for competitive bone marrow transplantation. B, T, and myeloid cell populations are depicted. Comparison of CD45.1/2 and CD45.2 constitution potential within (a) total bone marrow compartment, (b) T cells, (c) B cells, and (d) myeloid cells

\section{Notes}

1. Ideally, CD $45.1^{\text {STEM }}$ and CD $45.1^{\text {STEM }} / 2$ mice would be used for competitive transplantation assays. Given that the B6.SJL (CD45.1) mouse strain is more widely available and for practical reasons this protocol will use B6.SJL (CD45.1) as the recipient. We highly recommend using CD45.2 (WT) transplanted with 
CD45.1/2 donor mice as controls in parallel to the CD45.2 (GMO) transplantations. However, CD45.1 mice can be replaced with CD45.1 ${ }^{\text {STEM }}$ if they are available to you.

CD45.1 mice are designated as recipient, since the heterozygous genotype of CD $45.1 / 2$ mouse strains make it less frequent compared to the homozygote CD45.1 mouse strains.

2. Avoid using smaller gauge ( $<29$ gauge) needles as this can lead to increase shearing of cells in the inocula.

3. Alternative panel for FACS. When using the FITC channel for other purposes such as a GFP reporter cells, we suggest an alternative antibody cocktail for FACS.

Other alternative fluorochromes might be equally used.

\begin{tabular}{lll}
\hline Antibody & Fluorochrome & Clone \\
\hline CD45.1 & PE-Cy7 & A20 \\
\hline CD45.2 & Pacific Blue & 104 \\
\hline CD11b & APC-Cy7 & M1/70 \\
\hline CD3 & PE & UCHT1 \\
\hline B220 & Alexa Fluor 700 & RA3-6B2 \\
\hline Gr-1 & APC & RB6-8C5 \\
\hline
\end{tabular}

4. To help reduce the stress of mice, place some of the nesting material into the acrylic container.

5. An alternative method to restrain and inject mice.

Materials

(a) 1-pound weight.

(b) 11 beaker.

(c) 29-gauge needles.

(d) $1 \mathrm{ml}$ syringe.

Method

(a) With tape or another adhesive, secure a l-pound weight onto the outside bottom of a 11 beaker.

(b) Bend the tip of the syringe $90^{\circ}$ with the lumen of the needle facing upwards. By bending the needle $90^{\circ}$, the injection can then be done parallel to the tail with greater ease.

(c) Place the mice under the 11 beaker, with their tail exposed from the small spout. The weight should be heavy enough to secure the mice under the beaker; otherwise add more weights.

(d) Inject with the lumen of the needle facing upwards.

This method gives more stability to inject and mice show less stress. 


\section{References}

1. Weissman IL (2000) Stem cells: units of development, units of regeneration, and units in evolution. Cell 100(1):157-168

2. Orkin SH, Zon LI (2008) Hematopoiesis: an evolving paradigm for stem cell biology. Cell 132(4):631-644

3. He S, Nakada D, Morrison SJ (2009) Mechanisms of stem cell self-renewal. Annu Rev Cell Dev Biol 25(1):377-406

4. Seita J, Weissman IL (2010) Hematopoietic stem cell: self-renewal versus differentiation. Wiley Interdiscip Rev Syst Biol Med 2 (6):640-653

5. Cabezas-Wallscheid N, Klimmeck D, Hansson J, Lipka Daniel B, Reyes A, Wang Q, Weichenhan D, Lier A, von Paleske L, Renders $S$, Wünsche $P$, Zeisberger $P$, Brocks D, Gu L, Herrmann C, Haas S, Essers MAG, Brors B, Eils R, Huber W, Milsom MD, Plass C, Krijgsveld J, Trumpp A (2014) Identification of regulatory networks in HSCs and their immediate progeny via integrated proteome, transcriptome, and DNA methylome analysis. Cell Stem Cell 15(4):507-522

6. Wilson A, Laurenti E, Oser G, van der Wath RC, Blanco-Bose W, Jaworski M, Offner S, Dunant CF, Eshkind L, Bockamp E, Lió P, MacDonald HR, Trumpp A (2008) Hematopoietic stem cells reversibly switch from dormancy to self-renewal during homeostasis and repair. Cell 135(6):1118-1129

7. van der Wath RC, Wilson A, Laurenti E, Trumpp A, Liò P (2009) Estimating dormant and active hematopoietic stem cell kinetics through extensive modeling of bromodeoxyuridine label-retaining cell dynamics. PLoS One 4(9):e6972

8. Qiu J, Papatsenko D, Niu X, Schaniel C, Moore K (2014) Divisional history and hematopoietic stem cell function during homeostasis. Stem Cell Reports 2(4):473-490

9. Bernitz JM, Kim HS, MacArthur B, Sieburg H, Moore K (2016) Hematopoietic stem cells count and remember self-renewal divisions. Cell 167(5):1296-1309.e1210

10. Cantor AB, Orkin SH (2001) Hematopoietic development: a balancing act. Curr Opin Genet Dev 11(5):513-519

11. Miyamoto T, Iwasaki H, Reizis B, Ye M, Graf T, Weissman IL, Akashi K (2002) Myeloid or lymphoid promiscuity as a critical step in hematopoietic lineage commitment. Dev Cell 3(1):137-147

12. Adolfsson J, Månsson $\mathrm{R}$, Buza-Vidas $\mathrm{N}$, Hultquist A, Liuba K, Jensen CT, Bryder D,
Yang L, Borge O-J, Thoren LAM, Anderson K, Sitnicka E, Sasaki Y, Sigvardsson M, Jacobsen SEW (2005) Identification of Flt3+ lymphomyeloid stem cells lacking erythromegakaryocytic potential: a revised road map for adult blood lineage commitment. Cell 121 (2):295-306

13. Forsberg EC, Serwold T, Kogan S, Weissman IL, Passegué E (2006) New evidence supporting megakaryocyte-erythrocyte potential of Flk2/Flt3+ multipotent hematopoietic progenitors. Cell 126(2):415-426

14. Essers MAG, Offner S, Blanco-Bose WE, Waibler Z, Kalinke U, Duchosal MA, Trumpp A (2009) IFN $\alpha$ activates dormant haematopoietic stem cells in vivo. Nature 458:904-908

15. Baldridge MT, King KY, Boles NC, Weksberg DC, Goodell MA (2010) Quiescent haematopoietic stem cells are activated by IFN- $\gamma$ in response to chronic infection. Nature 465:793-797

16. Takizawa H, Regoes RR, Boddupalli CS, Bonhoeffer S, Manz MG (2011) Dynamic variation in cycling of hematopoietic stem cells in steady state and inflammation. J Exp Med 208 (2):273-284

17. Walter D, Lier A, Geiselhart A, Thalheimer FB, Huntscha S, Sobotta MC, Moehrle B, Brocks D, Bayindir I, Kaschutnig P, Muedder K, Klein C, Jauch A, Schroeder T, Geiger H, Dick TP, Holland-Letz T, Schmezer P, Lane SW, Rieger MA, Essers MAG, Williams DA, Trumpp A, Milsom MD (2015) Exit from dormancy provokes DNAdamage-induced attrition in haematopoietic stem cells. Nature 520:549-552

18. Cabezas-Wallscheid N, Buettner F, Sommerkamp P, Klimmeck D, Ladel L, Thalheimer FB, Pastor-Flores D, Roma LP, Renders S, Zeisberger P, Przybylla A, Schönberger K, Scognamiglio R, Altamura S, Florian CM, Fawaz M, Vonficht D, Tesio M, Collier P, Pavlinic D, Geiger H, Schroeder T, Benes V, Dick TP, Rieger MA, Stegle O, Trumpp A (2017) Vitamin A-retinoic acid signaling regulates hematopoietic stem cell dormancy. Cell 169(5):807-823.e19

19. Guralnik JM, Eisenstaedt RS, Ferrucci L, Klein HG, Woodman RC (2004) Prevalence of anemia in persons 65 years and older in the United States: evidence for a high rate of unexplained anemia. Blood 104(8):2263-2268

20. Lichtman MA, Rowe JM (2004) The relationship of patient age to the pathobiology of the clonal myeloid diseases. Semin Oncol 31 (2):185-197 
21. Linton PJ, Dorshkind K (2004) Age-related changes in lymphocyte development and function. Nat Immunol 5:133-139

22. Miller JP, Allman D (2003) The decline in B lymphopoiesis in aged mice reflects loss of very early B-lineage precursors. J Immunol 171 (5):2326-2330

23. Rossi DJ, Bryder D, Zahn JM, Ahlenius H, Sonu R, Wagers AJ, Weissman IL (2005) Cell intrinsic alterations underlie hematopoietic stem cell aging. Proc Natl Acad Sci U S A 102 (26):9194-9199

24. Geiger H, de Haan G, Florian MC (2013) The ageing haematopoietic stem cell compartment. Nat Rev Immunol 13:376-389

25. Rossi DJ, Bryder D, Seita J, Nussenzweig A, Hoeijmakers J, Weissman IL (2007) Deficiencies in DNA damage repair limit the function of haematopoietic stem cells with age. Nature 447:725-729

26. Cho RH, Sieburg HB, Muller-Sieburg CE (2008) A new mechanism for the aging of hematopoietic stem cells: aging changes the clonal composition of the stem cell compartment but not individual stem cells. Blood 111 (12):5553-5561

27. Dykstra B, Olthof S, Schreuder J, Ritsema M, de Haan G (2011) Clonal analysis reveals multiple functional defects of aged murine hematopoietic stem cells. J Exp Med 208 (13):2691-2703

28. Flach J, Bakker ST, Mohrin M, Conroy PC, Pietras EM, Reynaud D, Alvarez S, Diolaiti ME, Ugarte F, Forsberg EC, Le Beau MM, Stohr BA, Méndez J, Morrison CG, Passegué $\mathrm{E}$ (2014) Replication stress is a potent driver of functional decline in ageing haematopoietic stem cells. Nature 512(7513):198-202

29. Tuljapurkar SR, McGuire TR, Brusnahan SK, Jackson JD, Garvin KL, Kessinger MA, Lane JT, O'Kane BJ, Sharp JG (2011) Changes in human bone marrow fat content associated with changes in hematopoietic stem cell numbers and cytokine levels with aging. J Anat 219(5):574-581

30. Ergen AV, Boles NC, Goodell MA (2012) Rantes/Ccl5 influences hematopoietic stem cell subtypes and causes myeloid skewing. Blood 119(11):2500-2509

31. Harrison D (1980) Competitive repopulation: a new assay for long-term stem cell functional capacity. Blood 55(1):77-81

32. Shen FW, Saga Y, Litman G, Freeman G, Tung JS, Cantor H, Boyse EA (1985) Cloning of Ly-5 cDNA. Proc Natl Acad Sci U S A 82 (21):7360-7363

33. Yakura H, Shen FW, Bourcet E, Boyse EA (1983) On the function of Ly-5 in the regulation of antigen-driven B cell differentiation. Comparison and contrast with Lyb-2. J Exp Med 157(4):1077-1088

34. Spangrude G, Heimfeld S, Weissman I (1988) Purification and characterization of mouse hematopoietic stem cells. Science 241 (4861):58-62

35. Waterstrat A, Liang Y, Swiderski CF, Shelton BJ, Van Zant G (2010) Congenic interval of CD45/Ly-5 congenic mice contains multiple genes that may influence hematopoietic stem cell engraftment. Blood 115(2):408-417

36. Mercier FE, Sykes DB, Scadden DT (2016) Single targeted exon mutation creates a true congenic mouse for competitive hematopoietic stem cell transplantation: the C57BL/6CD45.1 (STEM) mouse. Stem Cell Reports 6 (6):985-992

37. Flurkey KCJ, Harrison DE (2007) The mouse in aging research. In: Fox JG et al (eds) The mouse in biomedical research, 2nd edn. American College Laboratory Animal Medicine, Elsevier, pp 637-672

38. Eaves CJ (2015) Hematopoietic stem cells: concepts, definitions, and the new reality. Blood 125(17):2605-2613 